\title{
Investigation of Pectin-Hydroxypropyl Methylcellulose-Coated Floating Beads for Pulsatile Release of Piroxicam
}

\author{
Pektin-Hidroksipropil Metilselüloz Kaplı Yüzer Mikro Küreciklerin \\ Piroksikamın Pulsatil Salımı Açısından Araştırılması
}

\author{
(D) Dipali KAMBLE, (D) Dilesh SINGHAVI*, (D) Shrikant TAPADIA, (D) Shagufta KHAN \\ Borgaon (Meghe) Institute of Pharmaceutical Education and Research, Wardha, Maharashtra, India
}

\begin{abstract}
Objectives: The aim of the present study was to prepare pectin-hydroxypropyl methylcellulose-coated floating beads for pulsatile release of piroxicam in the treatment of early morning inflammation.

Materials and Methods: Piroxicam-loaded beads were prepared from sodium alginate and hydroxypropyl methylcellulose (HPMC) in different concentrations of calcium carbonate using the ionotropic gelation method. In order to avoid drug release in the upper part of the gastrointestinal tract, the beads were coated with a pectin-HPMC layer using the dip coating method. Size analysis and encapsulation efficiency, drug loading, in vitro release, swelling behavior, and surface morphology studies of the beads were carried out.

Results: The in vitro release study revealed that the pectin-HPMC coating of the beads prevented the release of the drug in an acidic medium and provided pulsed release of the drug after a lag time. Formulation CF4 (containing calcium carbonate in the ratio 3:4 with respect to sodium alginate) exhibited pulsed release of $95.55 \%$ at the end of $7 \mathrm{~h}$ in phosphate buffer, which was after the desired lag time of $6 \mathrm{~h}$.

Conclusion: The study revealed that optimized floating pulsatile beads coated with pectin-HPMC can efficiently retain piroxicam in an acidic medium and that there is pulsed release in an alkaline medium after a lag time. It also showed that the beads prepared can potentially be used for chronotherapeutic treatment of the disease associated with early morning inflammation.
\end{abstract}

Key words: Beads, floating, hydroxypropyl methylcellulose, pectin, pulsatile

öz

Amaç: Bu çalışmanın amacı, sabah erken enflamasyonun tedavisinde kullanılmak üzere pulsatil piroksikam salımı yapan pektin-hidroksipropil metilselüloz kaplı yüzer mikro küreciklerin hazırlanmasıdır.

Gereç ve Yöntemler: Piroksikam yüklü mikroküreler, iyonotropik jelleştirme yöntemi kullanılarak kalsiyum karbonatın farklı konsantrasyonları içinde sodyum aljinat ve hidroksipropil metilselülozdan (HPMC) hazırlandı. Gastrointestinal sistemin üst kısmında ilaç salımını önlemek için mikro küreler daldırmalı kaplama yöntemi kullanılarak pektin-HPMC tabakası ile kaplandı. Mikrokürelerin boyut analizi ve enkapsülasyon verimi, ilaç yükleme, in vitro salım, şişme davranışı ve yüzey morfolojisi çalışmaları yapıımışıır.

Bulgular: In vitro salım çalışması, mikrokürelerin pektin-HPMC kaplamasının ilacın asidik ortamda salınmasını önlediğini ve bir gecikme süresinden sonra ilacın pulsatil salımını sağladığını ortaya koymuştur. Formülasyon CF4 (sodyum alginata göre 3:4 oranında kalsiyum karbonat içerir), istenen 6 saatlik gecikme süresinden sonra fosfat tamponunda 7 saatin sonunda\%95,55'lik pulsatil salım sergilediği bulunmuştur.

Sonuç: Çalışma, pektin-HPMC ile kaplanmış, optimize edilmiş yüzen pulsatil mikrokürelerin, piroksikam etken maddesinin asidik ortamda koruyarak tutabildiğini ve bir gecikme süresinden sonra alkali ortamda pulsatil salım yaptığını ortaya koymuştur. Ayrıca, hazırlanan boncukların potansiyel olarak sabah erken iltihaplanma ile bağlantılı hastalığın kronoterapötik tedavisi için kullanılabileceğini gösterdi.

Anahtar kelimeler: Mikroküreler, hidroksipropil metilselüloz, pektin, pulsatil

*Correspondence: E-mail: dileshsinghavi@rediffmail.com, Phone: 07152240284 ORCID-ID: orcid.org/0000-0002-2544-7226

Received: 03.06.2019, Accepted: 05.09.2019

๑Turk J Pharm Sci, Published by Galenos Publishing House. 


\section{INTRODUCTION}

Drug delivery systems based on circadian variations are gaining much attention. 'Several diseases treated by chronotherapeutics, such as asthma, hypertension, arthritis, and peptic ulcers, require an instantaneous and complete release of a drug after a scheduled time for effective action. Pulsatile drug delivery systems are developed to deliver drugs at the right time, in the right amount, and at the right site of action and thus improve patient compliance. ${ }^{2}$ Time-controlled and site-specific drug delivery systems must be programmed such that they can be administered at bedtime and the drugs are released rapidly when the symptoms worsen. Pulsatile drug delivery systems have a short residence time in the stomach although they release drugs after a certain lag time. Different approaches have been developed to improve the retention time and bioavailability of drugs in the gastrointestinal tract (GIT), such as intragastric floating formulations, magnetic formulations, extensible or swellable formulations, and superporous hydrogel gel formulations. ${ }^{3}$ Multiple-unit dosage forms have various advantages over monolithic-type dosage forms in reducing intersubject and intrasubject variabilities of transit due to the all-or-nothing emptying process. Various approaches have been used to impart buoyancy to multiple-unit dosage forms. These involve effervescent or noneffervescent systems. ${ }^{4,5}$ Jagdale et al. ${ }^{6}$ developed press-coated floating pulsatile tablets of lisinopril for the treatment of hypertension. Gadad et al. ${ }^{7}$ formulated hollow multiparticulate floating formulations using low-methoxy pectin (LM-PC) and gellan gum as polymers for site- and time-specific delivery of antihypertensive drugs.

The aim of the present investigation was to design and evaluate floating pulsatile beads of piroxicam (PX). LM-PC can be used as a coating material to avoid drug release in an acidic medium. LM-PC has a strong coating film-forming property, but it is highly soluble in water. Due to this water solubility, it cannot be used to prevent the release of PX to a great extent in the upper GIT. Absorption of water may lead to weakening of the rigid gel structure of an LM-PC coating. The use of hydroxylpropyl methylcellulose (HPMC) E50 LV along with LM-PC not only maintains the gel structure but also gives strength and better coating properties. ${ }^{8,9}$ PX was incorporated in sodium alginate (SA) and HPMC E50 LV polymeric membrane along with a gasforming agent (calcium carbonate) so that the beads would remain buoyant in the stomach for a longer duration. The addition of LM-PC to the HPMC E50 LV coating layer to reduce the release of PX from floating pulsatile beads in an acidic medium is reported for the first time in the present work. The prepared beads were coated with LM-PC-HPMC E50 LV to prevent drug release in the upper portion of the GIT. The prepared beads were analyzed in terms of size, swelling and erosion, drug loading, encapsulation efficiency, floating properties, and in vitro drug release. Fourier transform infrared spectroscopy was carried out and their surface morphology was studied.

\section{MATERIALS AND METHODS}

\section{Materials}

PX was a gift sample from Apex Health Care Ltd (Gujarat). SA, HPMC K15M, LM-PC, HPMC E50 LV, and calcium chloride were obtained from LOBA Chemical Pvt Ltd (Mumbai). All other chemicals were of analytical grade.

\section{Selection of polymer combinations}

Nine formulations were made using the ionotropic gelation method with SA and different polymers (xanthan gum, HPMC K100 M, and HPMC K15 M) in different ratios, keeping total polymer weight constant. The concentrations of the drug, crosslinking agent $(2 \% \mathrm{w} / \mathrm{v}$ calcium chloride solution in $1 \%$ $\mathrm{v} / \mathrm{v}$ acetic acid aqueous solution), and floating agent were maintained constant, as shown in Table 1 . The beads were observed and a promising polymer ratio was selected visually.

Effect of concentration of calcium chloride on formation of beads

The polymers selected from a previous study, HPMC K15 M and SA, were weighed accurately in the ratio 9.3:0.7. The HPMC

\section{Table 1. Preliminary selection of polymer combinations and ratios for preparation of beads}

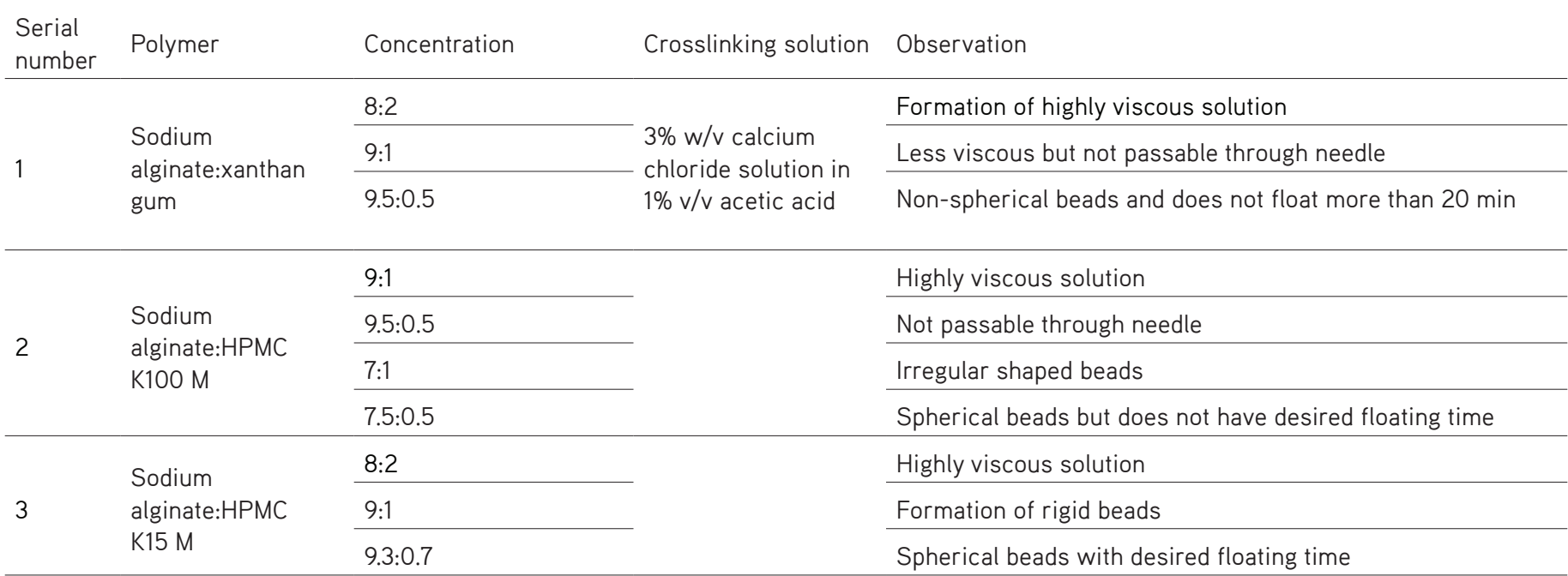

HPMC: Hydroxpropyl methylcellulose 
K15 M was soaked overnight in deionized water and the SA was dissolved in it. A syringe with a $23 \mathrm{G}$ needle was used to extrude the resultant solution into $50 \mathrm{~mL}$ of a crosslinking solution containing different concentrations of calcium chloride $(2 \%, 3 \%$, and $4 \% \mathrm{w} / \mathrm{v})$. The effect of concentration of calcium chloride on the formation of beads was observed visually. The polymer combination of SA:HPMC K15 M in the ratio 9.3:0.7 and a $3 \%$ calcium chloride crosslinking solution were selected for further studies.

\section{Preparation of PX-loaded floating pulsatile beads ${ }^{10}$}

PX-loaded beads were prepared using the ionotropic gelation method. An aqueous polymeric solution (10\% w/v) of SA and HPMC K15 M (in the ratio 9.3:0.7) was prepared using deionized water. PX was dispersed uniformly using a magnetic stirrer running at a speed of $150 \mathrm{rpm}$. Calcium carbonate at different concentrations was added to this mixture as shown in Table 2 , and the resulting dispersion was sonicated for $15 \mathrm{~min}$ in a sonicator to remove any air bubbles that formed during the mixing process. The prepared dispersion was extruded using a $23 \mathrm{G}$ needle and syringed into a crosslinking solution ( $3 \% \mathrm{w} / \mathrm{v}$ calcium chloride solution in deionized water containing $1 \% \mathrm{v} / \mathrm{v}$ acetic acid). The loosely formed beads were cured by stirring at $150 \pm 5 \mathrm{rpm}$ for $15 \mathrm{~min}$. The prepared beads were separated by filtration, washed three times with deionized water, and subsequently dried at room temperature.

\section{Coating of floating pulsatile beads}

Film-forming study ${ }^{10,11}$

The solvent casting method was used to prepare films. LMPC $(2 \% \mathrm{w} / \mathrm{v})$ and HPMC E50 LV $(0.1 \% \mathrm{w} / \mathrm{v})$ were dissolved in deionized water and allowed to stand and swell. A plasticizer (polyethylene glycol 600/0.1\% v/v) was added dropwise so that a homogeneous solution was achieved. The solution was kept undisturbed for some time to allow air bubbles to escape. The solution was poured into a petri dish. The petri dish was maintained at $40{ }^{\circ} \mathrm{C}$ for $24 \mathrm{~h}$ to achieve evaporation in a controlled manner. The film-forming ability, physical appearance, and texture of the coating solution were evaluated visually.

\section{Procedure for coating beads}

PX-loaded uncoated beads were dip coated uniformly in coating solution containing LM-PC ( $2 \% \mathrm{w} / \mathrm{v})$ and HPMC E50 LV $(0.1 \% \mathrm{w} / \mathrm{v})$ for $3 \mathrm{~min}$. The coated beads were dried at room temperature and kept in an airtight container for further use.

\section{Encapsulation efficiency and drug-loading efficiency ${ }^{12-14}$}

Accurately weighed PX-loaded beads $(50 \mathrm{~g})$ from each batch were crushed by mortar and pestle. The crushed beads were added to $50 \mathrm{~mL}$ of phosphate buffer $(\mathrm{pH} 7.4)$. The resulting solution was stirred using a magnetic stirrer for $24 \mathrm{~h}$ and filtered through Whatman filter paper 42 . The filtered solution was diluted sufficiently, and the absorbance was read at $353.80 \mathrm{~nm}$ with phosphate buffer $(\mathrm{pH}$ 7.4) as the blank solution. The percent encapsulation efficiency and drug loading were determined using the following equations:

$$
\begin{gathered}
\% \text { encapsulation efficiency }=\frac{\text { Actual drug content }}{\text { Theoretical drug content }} \times 100 \\
\% \text { drug loading }=\frac{\text { Weight of drug in beads }}{\text { Weight of drug-loaded beads }} \times 100
\end{gathered}
$$

Floating property study $12,13,15$

Floating properties of the beads, such as the total floating time and floating lag time, were determined by placing them $(n=50)$ in a USP type II Dissolution Apparatus (model no. DA-3, Veego Scientific Devices, Mumbai, India) filled with $500 \mathrm{~mL}$ of

\begin{tabular}{|c|c|c|c|c|c|c|}
\hline Formulation & $\begin{array}{l}\text { Composition of drug polymer } \\
\text { dispersion }(10 \mathrm{~mL})\end{array}$ & $\begin{array}{l}\text { Crosslinking } \\
\text { solution }(50 \mathrm{~mL})\end{array}$ & $\begin{array}{l}\text { Encapsulation } \\
\text { efficiency* (\% } \\
\text { w/w) }\end{array}$ & $\begin{array}{l}\text { Percent } \\
\text { drug } \\
\text { loading* (\% } \\
w / w)\end{array}$ & $\begin{array}{l}\text { Particle } \\
\text { size }^{\star \star}(\mathrm{mm})\end{array}$ & Floating study \\
\hline
\end{tabular}

\section{Table 2. Composition, encapsulation efficiency, percent drug loading, particle size, and floating properties of different batches of beads}

\begin{tabular}{|c|c|c|c|c|c|c|c|c|c|c|c|}
\hline & $\begin{array}{l}\text { Drug } \\
\text { (mg) }\end{array}$ & $\begin{array}{l}\text { SA } \\
(\mathrm{mg})\end{array}$ & $\begin{array}{l}\text { HPMC k15 } \\
\text { M (mg) }\end{array}$ & $\begin{array}{l}\text { Calcium } \\
\text { carbonate } \\
\text { (mg) }\end{array}$ & $\begin{array}{l}\mathrm{CaCl}_{2} \\
(\% \mathrm{w} / \mathrm{v})\end{array}$ & $\begin{array}{l}\text { Acetic } \\
\text { acid (\% } \\
\text { v/v) }\end{array}$ & & & & $\begin{array}{l}\text { Floating } \\
\text { property }\end{array}$ & $\begin{array}{l}\text { Floating } \\
\text { duration* } \\
\text { (hours) }\end{array}$ \\
\hline $\mathrm{F} 1$ & 20 & 465 & 35 & 0 & 3 & 1 & $98.56 \pm 0.12$ & $28.15 \pm 0.15$ & $1.348 \pm 0.012$ & +- & $3.20 \pm 0.30$ \\
\hline $\mathrm{F} 2$ & 20 & 465 & 35 & 116.25 & 3 & 1 & $96.73 \pm 0.13$ & $23.70 \pm 0.22$ & $1.413 \pm 0.014$ & +- & $4.30 \pm 0.07$ \\
\hline F3 & 20 & 465 & 35 & 232.5 & 3 & 1 & $95.84 \pm 0.11$ & $20.48 \pm 0.18$ & $1.521 \pm 0.018$ & ++ & $5.18 \pm 0.03$ \\
\hline F4 & 20 & 465 & 35 & 348 & 3 & 1 & $95.03 \pm 0.28$ & $18.05 \pm 0.15$ & $1.542 \pm 0.015$ & ++ & $6.15 \pm 0.06$ \\
\hline F5 & 20 & 465 & 35 & 465 & 3 & 1 & $90.12 \pm 0.23$ & $15.30 \pm 0.13$ & $1.576 \pm 0.011$ & ++ & 12 \\
\hline
\end{tabular}

*Mean \pm SD $(n=3),{ }^{*}$ Mean \pm SD ( $\left.n=20\right),++$ indicates better floating property (45-50 beads floated), + - moderate floating property (20-25 beads floated)

SA: Sodium alginate, HPMC: Hydroxypropyl methylcellulose, SD: Standard deviation 
$\mathrm{pH} 1.2$ buffer. The paddle speed was kept at $100 \mathrm{rpm}$ and the temperature was maintained at $37 \pm 0.5{ }^{\circ} \mathrm{C}$. The buoyancy of the beads was observed by visual inspection.

Particle size analysis ${ }^{12-14}$

An imaging system (Biowizard Software 4.1) was used to determine the particle size of the beads. The diameters of 20 beads were determined.

In vitro drug release $e^{13-15}$

The release profiles of the PX from the different formulations were obtained using a USP type I Dissolution Apparatus operated at $100 \mathrm{rpm}$. Prepared beads equivalent to $20 \mathrm{mg}$ of PX were kept in a basket that was inserted in $500 \mathrm{~mL}$ of the dissolution medium at $37 \pm 0.5{ }^{\circ} \mathrm{C}$. A release study was carried out with a pH 1.2 buffer for the first $2 \mathrm{~h}$ and then with a phosphate buffer ( $\mathrm{pH}$ 7.4) for $10 \mathrm{~h}$. Samples were withdrawn at predetermined time periods and passed through Whatman filter paper. The samples were then diluted sufficiently and analyzed spectrophotometrically at $335 \mathrm{~nm}$ and $353.8 \mathrm{~nm}$ in a pH 1.2 buffer and $\mathrm{pH} 7.4$ phosphate buffer, respectively. The amount of drug release was determined from the standard calibration curve of PX in both media. The calibration curve in both media obeyed Beer-Lambert's law within the concentration range of $0-20(\mu \mathrm{g} / \mathrm{mL})$ with a correlation coefficient $\left(R^{2}\right)$ of 0.999 .

\section{Swelling study 16}

Accurately weighed beads (40 mg) were placed in the basket of a USP type I Dissolution Apparatus containing $500 \mathrm{~mL}$ of a buffer solution. Considering the floating characteristics of the beads, the swelling study was carried out in a $\mathrm{pH} 1.2$ buffer solution and then in a $\mathrm{pH} 7.4$ phosphate buffer maintained at $37 \pm 0.5^{\circ} \mathrm{C}$ with the basket being rotated at $100 \mathrm{rpm}$. The baskets were withdrawn at predetermined intervals, blotted to remove excess water, and immediately weighed. The swelling index of the beads was calculated as the relative weight gain/loss of the beads according to the following equation:

$\%$ swelling index $=(3)$

where

Ws = weight of swollen beads

$W d=$ weight of dried beads

The change in swelling with time was noted.

\section{Scanning electron microscopy ${ }^{17}$}

The external morphology of the prepared beads (size, shape, and surface) was studied using scanning electron microscopy. The beads of the optimized batch (CF4) were kept on doublesided copper conductive tape (NEM Nisshin EM Co Ltd) fixed on aluminum stubs. The beads were then coated by sputtering with a thin layer of gold in a vacuum for $45 \mathrm{~s}$ at $\mathrm{l}=20 \mathrm{~mA}$ using a coating unit (Cressington 108 auto sputter coater, UK) to make them electrically conductive. They were then analyzed using a scanning electron microscope (Supra 5 Carl Zeiss, Germany) operated at $5 \mathrm{kV}$.

Stability study ${ }^{18,19}$

Stability was studied by maintaining the optimized formulation at $40 \pm 0.5{ }^{\circ} \mathrm{C}$ and $75 \pm 5 \% \mathrm{RH}$ for 90 days. The samples were tested for drug content after $0,30,60$, and 90 days. The formulation was analyzed for percent drug loading and floating ability. The physical appearance of the formulation was noted and an in vitro release study was carried out.

\section{Statistical analysis ${ }^{20}$}

All the data were represented as the mean \pm standard deviation. The drug entrapment efficiency, floating duration, and mean particle size were compared using One-Way ANOVA, and the difference between the means for significance was observed using Tukey's HSD post-hoc test (GraphPad Prism InStat software)

\section{RESULTS AND DISCUSSION}

Crosslinking of the alginate with the divalent calcium ion is responsible for the formation of beads. ${ }^{21}$ Carbon dioxide is liberated as gas bubbles in the chemical reaction between calcium carbonate and acetic acid. ${ }^{12}$ This was responsible for the floating of the beads.

The percent encapsulation efficiency of the PX-loaded uncoated formulations was in the range from $98.56 \pm 0.12 \%$ to $90.12 \pm 0.23 \% \mathrm{w} / \mathrm{w}$ (Table 2). The percent drug loading of the uncoated formulations F1-F5 was in the range from $28.15 \pm 0.15 \%$ to $15.30 \pm 0.13 \% \mathrm{w} / \mathrm{w}$. The percent drug loading of the coated formulations CF1-CF5 was in the range from $28.15 \pm 0.15 \%$ to $14.20 \pm 0.13 \% \mathrm{w} / \mathrm{w}$. A reduction in percent encapsulation efficiency and percent drug loading was observed due to an increase in the proportion of the gas-forming agent. The increased formation of gas led to a reduction in extent of the rigid structure of the beads due to increased pore density and diameter. This results in the leaching of the drug during the formation of the beads, which leads to reduced entrapment of drug molecules.112-15 No significant difference was observed ( $p>0.05$ ) in the percent drug loading between the coated and uncoated formulations.

Carbon dioxide gas was generated due to the reaction between the gas-forming agent, i.e. calcium carbonate, and the acidic medium. The generated gas was entrapped in a polymeric network of SA and HPMC K15M and imparted buoyancy to the beads. The floating properties of the uncoated beads and coated beads are shown in Tables 2 and 3. As the amount of gasforming agent present in the formulation during the formation of beads was increased, the floating duration increased. The increased porosity of the beads might be due to the generation of greater amounts of gases, which led to a reduction in the density of beads, resulting in the improved floating duration. The reduced proportion of the high-density SA in the beads also led to the formation of lighter beads. The paddle speed does not affect the floating properties of the beads. The beads were able to float until disintegration occurred. Thus, in both the coated and uncoated formulations, as the concentration of the gas-forming agent was increased, the porosity was increased, causing them to remain buoyant for a longer duration. ${ }^{12-15,22}$ The differences between the floating duration of the coated and uncoated formulations were insignificant ( $p>0.05$ ). 
Table 3. Percent drug loading, particle size, and floating properties of different batches of coated beads

\begin{tabular}{lllll} 
Formulation & $\begin{array}{l}\text { Percent drug } \\
\text { loading }(\% \mathrm{w} / \mathrm{w})\end{array}$ & Particle size** $(\mathrm{mm})$ & Floating study \\
\hline CF1 & & & Floating property & Floating duration* (hours) \\
\hline CF2 & $28.15 \pm 0.15$ & $1.431 \pm 0.014$ & +- & $3.31 \pm 0.03$ \\
\hline CF3 & $22.80 \pm 0.22$ & $1.587 \pm 0.047$ & +- & $4.42 \pm 0.02$ \\
\hline CF4 & $19.60 \pm 0.18$ & $1.611 \pm 0.033$ & ++ & $5.19 \pm 0.01$ \\
\hline CF5 & $18.01 \pm 0.15$ & $1.640 \pm 0.042$ & ++ & $6.12 \pm 0.01$ \\
\hline
\end{tabular}

*Mean \pm SD $(n=3)$, **Mean \pm SD ( $n=20),++$ indicates better floating property ( $45-50$ beads floated), + - moderate floating property (20-25 beads floated) SD: Standard deviation

The mean particle size of the formulations F1-F5 was in the range from $1.348 \pm 0.012 \mathrm{~mm}$ to $1.576 \pm 0.011 \mathrm{~mm}$, while that of the coated formulations was in the range from $1.431 \pm 0.014 \mathrm{~mm}$ to $1.661 \pm 0.061 \mathrm{~mm}$. From the results (Table 2 ), it may be seen that increasing the amount of gas-forming agent led to an increase in the bead diameter due to increases in the number and size of pores. Again, the formation of more gas resulted in a less dense bead structure of greater size. The beads of batch F5, with a higher concentration of gas-forming agent, were not spherical, in contrast to those of batch F1, containing no gasforming agent. This was due to expansion of carbon dioxide, which led to a rapid bursting of walls before they had hardened sufficiently.12-14 A significant difference ( $p<0.05$ ) was observed in particle size between the uncoated and coated formulations. It was observed that there was an appreciably high drug release from uncoated beads in an acidic medium (Figure 1), which is not desirable. This might be because a lower concentration of SA and a higher concentration of the gas-forming agent led to pore formation and faster release of drug. The increased floating duration also led to an increase in the duration over which the drug was released in an acidic medium. Beads were dip coated with a layer of LM-PC and HPMC E50 LV to reduce the release of the drug in acidic media. Formulation CF4 gave the desired lag time of $6 \mathrm{~h}$ in acidic medium and rapid release (95.55\% at the end of $7 \mathrm{~h}$ ) in the phosphate buffer. In contrast, formulations CF1 (lag time $3 \mathrm{~h}$ ), CF2 (lag time 4 h), CF3 (lag time $5 \mathrm{~h}$ ), and CF5 (lag time $12 \mathrm{~h}$ ) gave cumulative releases

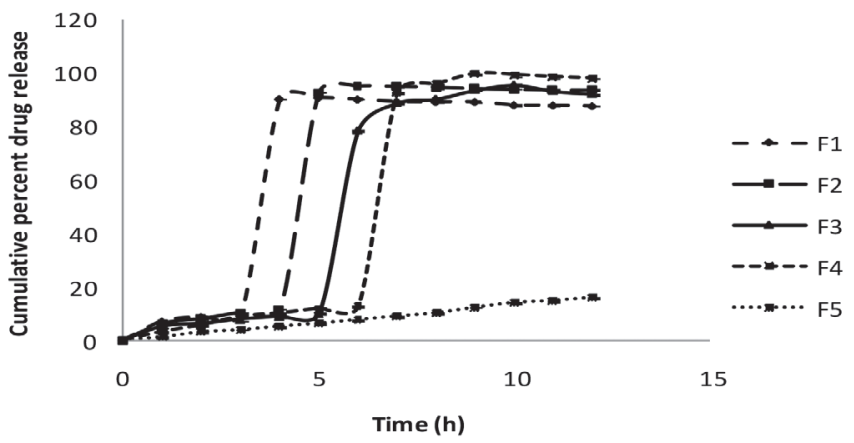

Figure 1. Cumulative amounts of $P X$ released from beads of formulations $F 1, F 2, F 3, F 4$, and F5 (mean $\pm S D, n=3$ )

SD: Standard deviation, PX: Piroxicam of $88.54 \%$ in 4 h, $93.15 \%$ in 5 h, $93.75 \%$ in 6 h, and $5 \%$ in 12 $h$, respectively (Figure 2). It was observed that the release of drug from the coated beads in acidic medium was significantly reduced compared with uncoated beads. The rigid gel structure of the PC and HPMC E50 LV coating led to a reduction in the diffusion of molecules from the inner core of the beads to an acidic medium. When the beads were transferred to the phosphate buffer of $\mathrm{pH} 7.4$ after the lag time, pulsed release was observed because of rapid swelling and gel relaxation of pectin in the alkaline $\mathrm{pH}^{1,13-15,21}$ As the floating duration of formulations F5 and CF5 was more than $12 \mathrm{~h}$, their lag time of release was also more than $12 \mathrm{~h}$. Formulations F5 and CF5 remained in acidic medium throughout the dissolution study, leading to very slow release rates.

The percent swelling study showed that formulations CF1-CF5 showed less swelling in the $\mathrm{pH} 1.2 \mathrm{HCl}$ buffer compared with a $\mathrm{pH} 7.4$ phosphate buffer (Figure 3 ). In an acidic $\mathrm{pH}$, pectin remains protonated in an insoluble form, with reduced swelling. The concentration of the gas-forming agent also acts as a barrier to the absorption of water. From the floating characteristics, formulation CF1, with no gas-forming agent, was found to have the maximum swelling. The swelling decreased with increasing concentration of gas-forming agent due to the formation of void spaces in the beads that retained the maximum volume of solvent. Thus, formulation CF5 showed the minimum floatingdependent swelling because of the high concentration of the gas-forming agent.

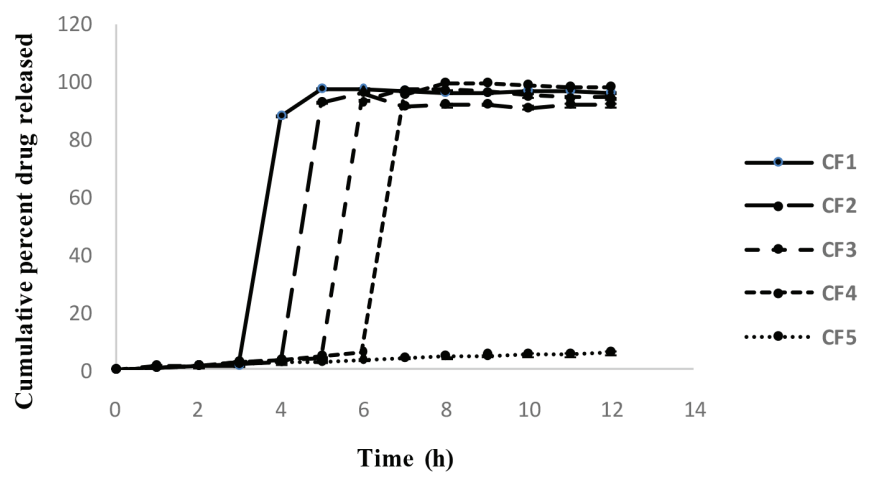

Figure 2. Cumulative amounts of $\mathrm{PX}$ released from beads of formulations CF1, CF2, CF3, CF4, and CF5 (mean \pm SD, $n=3$ )

SD: Standard deviation, PX: Piroxicam 


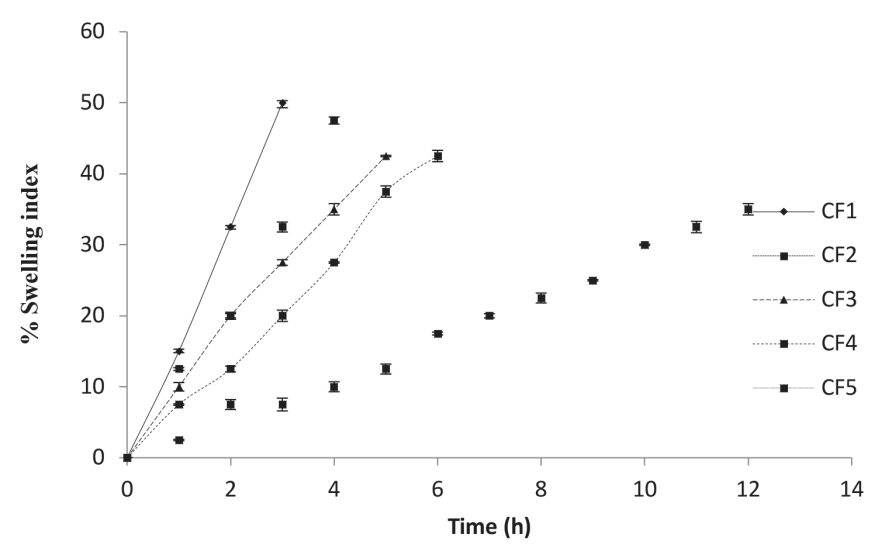

Figure 3. Percent swelling index of beads of formulations CF1, CF2, CF3, $\mathrm{CF} 4$, and CF5 (mean $\pm \mathrm{SD}, \mathrm{n}=3$ )

SD: Standard deviation

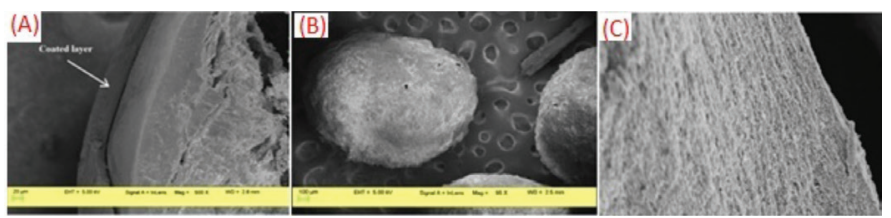

Figure 4. Morphological characterization of formulation CF4 using scanning electron microscopy A) showing coating layer, B) showing the roundness, and C) surface morphology

The uncoated beads of all the optimized formulations were seen to be almost spherical in the scanning electron photomicrographs (Figure 4). The beads with higher concentrations of the gasforming agent were porous, rough, and spherical. The high porosity of the beads was due to the rapid evolution of carbon dioxide during bead formation as the number of pores formed is directly related to the concentration of the gas-forming agent present..$^{15}$

After exposure to extreme conditions, formulation CF4 was analyzed for physical appearance, percent drug loading, floating ability, and in vitro drug release at an interval of 1 month. No significant changes $(p>0.01)$ were observed in the physical appearance, percent drug loading, floating ability, or in vitro drug release.

\section{CONCLUSION}

PX-loaded beads of SA and HPMC K15M were prepared using the ionotropic gelation method, and their performance was analyzed through in vitro experiments. The release of PX from uncoated beads in the acidic medium due to entry of the $\mathrm{Gl}$ fluid through the unprotected polymeric matrix was observed. Therefore, the beads were coated with a polymeric film of LMPC and HPMC E50 LV. Addition of HPMC E15 LV decreased the rupturing of the film and reduced the extent of premature drug release in the upper $\mathrm{Gl}$ tract. Overall, the buoyant beads exhibited gastroretention and provided a lag phase, followed by pulsatile drug release. These would be beneficial for treating the inflammation associated with chronotherapeutic diseases. Addition of HPMC E50 LV increased the flexibility, gelation, transparency, and mechanical properties of the LM PC films.
From the results it can be concluded that the PC: HPMC E50 LV-coated floating pulsatile beads can be used to treat the early morning inflammatory conditions in rheumatoid arthritis.

Conflicts of interest: No conflict of interest was declared by the authors. The authors alone are responsible for the content and writing of the paper.

\section{REFERENCES}

1. Badve S, Sher P, Korde A, Pawar A. Development of hollow/porous calcium pectinate beads for floating pulsatile drug delivery. Eur $J$ Pharm Biopharm. 2007;65:85-93.

2. Nief RA, Sulaiman HT, Jabir SA. Pulsatile drug delivery system-A review article. J Pharm Res. 2018;12:764-770.

3. Yao H, Yao H, Zhu J, Yu J, Zhang L. Preparation and evaluation of a novel gastric floating alginate/poloxamer inner-porous beads using foam solution. Int J Pharm. 2012;422:211-219.

4. Hamadani J, Moes AJ, Amighi K. Development and in vitro evaluation of a novel floating multiple unit dosage form obtained by melt pelletization. Int J Pharm. 2006;322:96-103.

5. Sungthongjeen S, Paeratakul O, Limmatvapirat S, Puttipipatkhachorn S. Preparation and in vitro evaluation of a multiple-unit floating drug delivery system based on gas formation technique. Int $J$ Pharm. 2006;324:136-143.

6. Jagdale S, Suryawanshi V, Pandya S, Kuchekar B, Chabukswar A. Development of press-coated, floating-pulsatile drug delivery of lisinopril. Sci Pharm. 2014;82:423-440.

7. Gadad AP, Reddy AD, Dandagi PM, Masthiholimath VS. Design and characterization of hollow/porous floating beads of captopril for pulsatile drug delivery. Asian J Pharm. 2014;6:137-143.

8. Sureshkumar R, Munikumar, Ganesh GNK, Jawahar N Nagasamyvenkatesh D, Senthil V, Raju L, Samantha MK. Formulation and evaluation of pectin-hydroxypropyl methylcellulose coated curcumin pellets for colon delivery. Asian J Pharm. 2009;138-142.

9. Turkoglu M, Ugurlu T. In vitro evaluation of pectin-HPMC compression coated 5-aminosalicylic acid tablets for colonic delivery. Eur J Pharm Biopharm. 2002; 53:65-73.

10. Newton AMJ, Prabakaran L, Jayaveera KN. Pectin-HPMC E15 LV Vs pH sensitive polymer coating film for delayed drug delivery to the colon-A comparison of two dissolution models to assess colonic targeting performance in-vitro. Int J Appl Res Nat Prod. 2012;5:1-16.

11. Hirpara F, Debnath SK, Saisivam S. Optimization and screening of different film forming polymers and plasticizers in fast dissolving sublingual film. Int J Pharm Pharm Sci. 2014;6:41-42.

12. Shishu, Gupta N, Aggrawal N. Stomach specific drug delivery of $\%$-flurouracil using floating alginate beads. AAPS Pharm Sci Tech. 2007;8:E143-E149.

13. Somani VG, Shahi SR, Udavant YK, Atram SC, Satpute R, Shinde NM A floating pulsatile drug delivery system based on hollow calcium pectinate beads. Asian J Pharmacol. 2009;120-124.

14. Gadad AP, Reddy AD, Dandagi PM, Masthiholimath VS. Design and characterization of hollow/porous floating beads of captopril for pulsatile drug delivery. Asian J Pharmacol. 2012:6:137-143.

15. Gadad A, Patil M, Naduvinamani S, Mastiholimath V, Dandagi P, Kulkarni A. Sodium alginate polymeric floating beads for the delivery of 
cefpodoxime proxetil. J Appl Polym Sci. 2009;114:1921-1926.

16. Lamoudi L, Chaumeil JC, Daoud K. Swelling, erosion and drug release characteristics of sodium diclofenac from heterogenous matrix tablet. J Drug Deliv Sci Technol. 2016;31:93-100.

17. Patel N, Lalwani D, Gollmer S, Injeti E, Sari Y, Nesamony J. Development and evaluation of calcium alginate based oral cefitriaxone sodium formulation. Prog Biomatter. 2016;:117-133.

18. Gadad AP, Reddy AD, Dandagi PM, Masthiholimath VS. Design and characterization of hollow/porous floating beads of captopril for pulsatile drug delivery. Asian J Pharm. 2012;6:137-143.

19. Rathnanand M, Pannalal S. Formulation and in vitro evaluation of floating pulsatile tablets of nizatidine for chronotherapy of ulcers. $J$ Pharm Res. 2011;4:1388-1390.

20. Patel MA, Aboughaly MH, Schryer-Praga JV, Chadwick K. The effect of ionotropic gelation residence time on alginate cross-linking and properties. Carbohyd Polym. 2017;155:362-371.

21. Bhattarai RS, Dhandapani NV, Shrestha A. Drug delivery using alginate and chitosan beads-An overview. Chron Young Sci. 2011;2:192-196.

22. Bajpai SK, Tankhiwale R. Preparation, characterization and preliminary calcium release study of floating sodium alginate/dextran-based hydrogel. Part I. Polym Int. 2008;57:57-65. 